\title{
PERANAN PROGRAM COMMUNITY DEVELOPMENT PERUSAHAAN BATUBARA MENINGKATKAN KESEJAHTERAAN MASYARAKAT (STUDI KASUS KABUPATEN TANAH BUMBU, KALIMANTAN SELATAN)
}

\author{
The Role of Community Development Coal Mining Company to \\ Increase Community Welfare (Case Study Tanah Bumbu, South \\ Kalimantan)
}

\author{
Wulan Metafurry ${ }^{1}$, Bambang Juanda², Eka Intan Kumala Putri ${ }^{3}$
}

Diterima: 25 Januari 2016 Disetujui: 18 April 2016

\begin{abstract}
Abstrak: Community development (comdev) merupakan salah satu bentuk dari pertanggungjawaban sosual perusahaan yang bertujuan untuk meningkatkan kesejahteraan masyarakat. Di sisi lain, comdev juga bertujuan untuk meminimumkan dampak negatif yang muncul akibat aktivitas pertambangan. Penelitian kali ini bertujuan untuk menganalisis manfaat comdev serta menghitung kontribusi comdev dalam peningkatan kesejahteraan masyarakat. Metode yang digunakan untuk menjawab pertanyaan penelitian adalah Second Order Confirmatory Factor Analysis (2nd CFA) dan regresi linier berganda dengan analisis komponen utama. Hasil dari penelitian menunjukkan bahwa manfaat dari comdev yang dilakukan oleh perusahaan tambang batubara telah dirasakan oleh masyarakat di Tanah Bumbu, Kalimantan Selatan. Comdev juga berkontribusi positif dalam peningkatan sumber daya manusia di Tanah Bumbu meskipun comdev masih belum cukup untuk mengkompensasi dampak negatif yang muncul akibat kegiatan pertambangan khususnya masalah lingkungan.
\end{abstract}

\section{Kata kunci: peran, batubara, masyarakat, kesejahteraan}

\begin{abstract}
Community development (comdev) is a form of corporate social responsibility program to increase community welfare. On the other side, comdev also aims to minimize the impact arising from mining activities. The present study aims to analyze the benefit of comdev and to calculate comdev contribution to increase community welfare. The method used to answer the research are Second Order Confirmatory Factor Analysis ( $2^{\text {nd }} \mathrm{CFA}$ ) and Multiple Linier Regression with Principal Component Analysis (PCA). The result show that benefit of comdev was perceived by community in Tanah Bumbu, South Kalimantan. Comdev also contributes positively to increase human resource development in Tanah Bumbu, but comdev not enough to compensate for the negative impact of mining especially enviromental issues.
\end{abstract}

Keywords: role, coal, community, welfare

\footnotetext{
${ }^{1}$ Sekolah Parca Sarjana, Institut Pertanian Bogor

${ }^{2}$ Fakultas Ekonomi dan Manajemen, Institut Pertanian Bogor

${ }^{3}$ Departemen Ekonomi Sumberdaya dan Lingkungan, Institut Pertanian Bogor
}

Korespondensi: metafurry.wulan@gmail.com 


\section{PENDAHULUAN}

Kalimantan Selatan merupakan salah satu provinsi dengan potensi batubara yang cukup besar. Pada tahun 2013, total produksi batubara di Kalimantan Selatan sebesar 163,815,779.23 mt. Salah satu kabupaten yang menjadi penghasil batubara di provinsi ini adalah Tanah Bumbu yang merupakan kabupaten kedua penghasil batubara terbanyak di Kalimantan Selatan. Namun, ironisnya pertumbuhan ekonomi Tanah Bumbu tidak sepesat pertumbuhan pertambangan batubara, dimana pertumbuhan ekonomi merupakan salah satu indikator kesejahteraan masyarakat. Salah satu upaya peningkatan kesejahteraan masyarakat di sekitar wilayah pertambangan adalah dengan melaksanakan program community development (comdev).

Tanah Bumbu merupakan kabupaten dimana kegiatan pertambangan dapat ditemukan hampir disemua kecamatan yang terdapat di Tanah Bumbu. Oleh karena itu, dampak yang ditimbulkan dari kegiatan pertambangan sangat dirasakan oleh masyarakat dan lingkungan setempat. Dampak tersebut dapat berupa dampak positif dan negatif. Dampak positif dari adanya kegiatan pertambangan adalah meningkatnya kondisi perekonomian wilayah tersebut. Sedangkan dampak negatifnya antara lain adalah adanya pencemaran lingkungan, berkurangnya luasan hutan di kabupaten tersebut (area tambang batubara mayoritas berada di kawasan hutan), hilangnya mata pencaharian penduduk akibat konversi lahan menjadi kawasan pertambangan. Comdev merupakan salah satu metode perusahaan pertambangan untuk mengkompensasi masyarakat atas dampak negatif akibat adanya kegiatan pertambangan. Dari sisi perusahaan, comdev berperan untuk menjaga keberlangsungan perusahaan, dimana dengan adanya program comdev diharapkan akan mampu menciptakan hubungan yang baik antara perusahaan dengan masyarakat sekitar.

Comdev adalah kegiatan pengembangan komunitas yang diarahkan untuk meningkatkan kemampuan komunitas dalam mencapai kondisi sosial-ekonomi-budaya yang lebih baik bila dibandingkan dengan sebelumnya (Budimanta 2002; Rudito dan Famiola 2013). Komunitas menjadi fokus pengembangan karena komunitas dapat menjelaskan mekanisme sosial budaya yang akan berdampak pada distribusi kesejahteraan (Smith 1980). Dengan adanya program comdev komunitas diharapkan menjadi lebih mandiri dan memiliki kualitas kehidupan dan kesejahteraan yang lebih baik. Meskipun demikian, tidak semua kegiatan comdev disambut baik oleh masyarakat, seperti yang terjadi di Kabupaten Kutai Kertanegara, dimana masyarakat beranggapan bahwa program yang dilakukan hanya merupakan strategi temporer perusahan dalam mengatasi permasalahan di masyarakat (Erwinatono dan Saleha 2012). Penelitian Alfitri (2010) menunjukan bahwa comdev justru menimbulkan ketergantungan masyarakat terhadap perusahaan. Selain dari perspektif masyarakat, implementasi comdev juga tidak sepenuhnya direalisasikan dalam program-program yang bertujuan untuk menumbuhkan kemandirian masyarakat melainkan untuk kepentingan perusahaan itu sendiri, seperti pembangunan sarana transportasi yang tujuan utama pembangunannya adalah untuk memfasilitasi kegiatan pertambangan itu sendiri. Disisi lain, partisipasi masyarakat setempat dalam kegiatan perencanaan dan implementasi comdev masih minim. Dari segi perekonomian, mayoritas program yang dilakukan berupa bantuan instan yang diberikan kepada masyarakat seperti bantuan sembako, santunan, dan lain-lain, sehingga dari sudut pandang perekonomian wilayah program tersebut tidak memberikan dampak yang signifikan.

Pelaksanaan comdev, dipayungi oleh beberapa peraturan perundang undangan, seperti Undang Undang No 40 Tahun 2007, Undang Undang Nomor 4 Tahun 2009, Peraturan Pemerintah No 23 Tahun 2010 serta Peraturan Pemerintah No 55 Tahun 2010. Melalui UU No. 40 Tahun 2007 tentang Perseroan Terbatas dan Undang-Undang Nomor 
4 Tahun 2009 Tentang Pertambangan Mineral dan Batubara, pemerintah telah mewajibkan Community Social Responsibility (CSR) dan comdev kepada semua perusahaan tambang. Undang Undang mengenai comdev sudah disahkan sejak tahun 2009, namun pelaksanaan comdev oleh perusahaan pertambangan di Tanah Bumbu mulai intensif dilaksanakan sejak tahun 2011. Meskipun telah disalurkan secara intensif, tidak menutup kemungkinan bahwa program yang diberikan belum memberikan manfaat yang optimal, baik bagi masyarakat penerima maupun bagi perekonomian wilayah. Selain itu, perlu dikaji apakah comdev yang telah diberikan sebanding dengan dampak negatif yang ditimbulkan akibat adanya kegiatan pertambangan. Berdasarkan rumusan masalah tersebut, maka tujuan dari penelitian ini adalah mengkaji manfaat pelaksanaan program comdev oleh perusahaan batubara di Kabupaten Tanah Bumbu, serta menghitung kontribusi program comdev perusahaan batubara terhadap peningkatan kualitas sumberdaya manusia yang dalam penelitian ini diukur melalui IPM Kabupaten Tanah Bumbu.

\section{METODE PENELITIAN}

Data yang digunakan dalam penelitian ini menggunakan data primer dan sekunder. Data primer diperoleh melalui observasi langsung di lapang dan wawancara dengan responden yang tersebar di empat kecamatan di Kabupaten Tanah Bumbu, yaitu kecamatan Satui, Angsana, Sungai Loban, dan Simpang Empat. Keempat kecamatan tersebut dipilih secara purpossive dengan kriteria merupakan wilayah yang telah menerima program comdev secara rutin dan intensif dari perusahaan tambang batubara. Responden dalam penelitian ini adalah masyarakat setempat yang merupakan penerima program tersebut. Pemilihan responden menggunakan teknik purpossive sampling dengan kriteria masyarakat yang menjadi responden adalah masyarakat yang mengetahui mengenai program comdev. Adapun total responden masyarakat pada penelitian ini adalah 130 responden yang tersebar di 13 desa di empat kecamatan. Dalam proses pengambilan data, peneliti dibantu oleh enumerator yang sebelumya telah diberi pembekalan (coaching) guna menyamakan persepsi mengenai materi kuesioner. Untuk memperdalam hasil analisis, dilakukan indepth interview dengan key person perusahaan pertambangan sebagai pelaksana program comdev serta tokoh masyarakat sebagai pengawas program comdev .

Selain data primer, penelitian ini juga menggunakan data sekunder. Data sekunder diperoleh dari perusahaan pelaksana program, Bappeda Kabupaten Tanah Bumbu, Dinas Pertambangan dan Energi Kabupaten Tanah Bumbu dan Badan Pusat Statistik. Data tersebut terdiri dari data pelaksanaan program comdev dan potensi wilayah.

Selanjutnya data yang diperoleh dianalisis dengan metode second order confirmatory factor analysis (2nd CFA) untuk mengajji manfaat comdev bagi masyarakat penerima bantuan. Alat analisis yang digunakan untuk menghitung peranan comdev terhadap peningkatan kualitas sumber daya manusia adalah regresi linier berganda dengan menggunakan analisis komponen utama (AKU).

\section{HASIL DAN PEMBAHASAN}

\section{Gambaran Umum Comdev di Tanah Bumbu}

Sektor pertambangan terutama pertambangan batubara merupakan salah satu sektor yang sangat berperan bagi perekonomian Kabupaten Tanah Bumbu. Kegiatan pertambangan di Kabupaten Tanah Bumbu telah dimulai sejak kabupaten ini masih merupakan bagian dari Kabupaten Kotabaru. Sebelum aktivitas pertambangan mulai berkembang, perekonomian di wilayah ini bergantung pada sektor pertanian. Sejak 
dilakukan eksplorasi pertambangan batubara, kontribusi sektor pertanian terhadap perekonomian wilayah makin berkurang dan digantikan dengan sektor pertambangan.

Sebagai tulang penggung dari perekonomian Tanah Bumbu, lokasi pertambangan batubara tersebar hampir di seluruh kecamatan yang terdapat di kabupaten tersebut. Lokasi penambangan tersebar sebagian besar di Kecamatan Satui, Simpang Empat dan Mantewe. Dari tahu ketahun, produksi batubara di Tanah Bumbu mengalami peningkatan. Selama tahun 2013, produksi batubara di kabupaten ini tercatat sebanyak 21,425,810.57 mt (BPS 2014) yang memberikan kontribusi positif pada PDRB Tanah Bumbu dengan share sebesar 43.87 persen. Namun, realisasinya pertumbuhan pertambangan di Tanah Bumbu tidak diimbangi dengan pertumbuhan kualitas hidup masyarakat setempat.

Tujuan utama comdev adalah untuk meningkatkan kualitas hidup masyarakat, oleh karenanya program-programnya ditujukan pada sektor ekonomi, pendidikan, kesehatan yang merupakan komponen utama untuk investasi di bidang sumber daya manusia, serta sektor infrastruktur yang merupakan sarana penunjang investasi tersebut. Bantuan tersebut diberikan kepada masyarakat yang berada di sekitar lokasi pertambangan yang dikelola oleh masing-masing perusahaan. Beberapa perusahaan mempunyai struktur organisasi tersendiri yang terpisah dengan operasional perusahaan untuk mengurus comdev. Bantuan tersebut ada yang diberikan dalam bentuk dana seperti bantuan modal dan beasiswa, barang seperti pemberian bantuan alat-alat kesehatan dan sarana prasarana pendidikan, maupun dalam bentuk jasa seperti pelayanan pengobatan gratis, pelatihan dan pendampingan. Dengan adanya SDM yang memadai diharapakan masyarakat dapat mencapai kesetaraan kondisi sosial ekonomi dalam artian yang lebih baik.

Selain peningkatan kondisi sosial ekonomi, kegiatan comdev juga memperhatikan dimensi lingkungan dimana program-program yang dilakukan tetap memperhatikan kondisi lingkungan setempat dalam artian program tersebut memanfaatkan sumberdaya secara tepat serta memperhatikan keanekaragaman hayati yang tersedia di masyarakat. Comdev yang dilaksanakan juga harus mampu memberikan perlindungan dan konservasi terhadap sumber daya lingkungan. Dengan adanya kondisi lingkungan yang memadai dengan kondisi sosial ekonomi masyarakat yang berkualiatas diharapkan akan tercipta pembangunan yang berkelanjutan pada wilayah tersebut, dimana comdev memberikan kontribusi yang signifikan dalam prosesnya.

Penyaluran dana comdev pada setiap perusahaan berbeda-beda, demikian juga untuk setiap programnya. Dana tersebut ada yang disalurkan melalui perusahaan itu sendiri dimana beberapa perusahaan telah memiliki organisasi tersendiri yang khusus untuk menangani program comdev, melalui lembaga masyarakat setempat, pemerintah daerah setempat, kepada instansi penerima bantuan (sekolah, puskesmas, rumah sakit), maupun langsung kepada masyarakat penerima. Penyaluran dana comdev didasarkan pada beberapa pertimbangan, seperti kebutuhan masyarakat dan lokasi. Semakin dekat lokasi suatu wilayah dengan lokasi pertambangan, maka bantuan yang diberikan juga semakin besar. Hal ini dikarenakan dampak yang diterima oleh masyarakat disekitar lokasi tambang lebih besar. Meskipun demikian, dalam penyalurannya perusahaan tetap mempertimbangkan kebutuhan masyarakat sebagai penerima.

\section{Analisis Manfaat Pelaksanaan Comdev}

Tujuan kegiatan comdev adalah untuk meningkatkan kondisi sosial-ekonomi-budaya masyarakat di sekitar lokasi pertambangan (Budimanta et al. 2004). Suatu program dinilai berhasil jika objek penerima (masyarakat) dapat merasakan manfaat dari kegiatan tersebut. Evaluasi manfaat comdev dilihat berdasarkan sektor ekonomi, pendidikan, kesehatan dan infrastruktur. Pada penelitian ini, evaluasi manfaat kegiatan comdev diukur dengan metode pengukuran $2^{\text {nd }} \mathrm{CFA}$. 
$2^{\text {nd }}$ CFA terdiri dari dua tingkatan CFA, dimana tingkat pertama menunjukkan hubungan antara variabel manifes dengan variabel label laten tingkat pertama, yaitu sektor ekonomi, pendidikan, kesehatan dan infrastruktur. Sedangkan CFA tingkat kedua menunjukan hubungan antara variabel laten tingkat pertama dengan variabel laten tingkat kedua, yaitu manfaat program. Sebelum melakukan analisis terhadap model 2nd CFA, terlebih dahulu dilihat kelayakan model yang dibangun melalui Goodness of Fit Statistic (GOF). Hasil GOF model yang dihasilkan cukup baik dengan nilai chi square 61.88 dan probabilitas 0.44 (lebih dari 0.05), selain itu nilai RMSEA yang diperoleh cukup kecil yaitu 0.026 atau dapat dikatakan model yang diperoleh close to fit (Bagozzi et al. 1988), dengan demikian dapat dilakukan analisis terhadap model yang diperoleh. Hasil analisis evaluasi manfaat comdev ditampilkan pada gambar berikut.

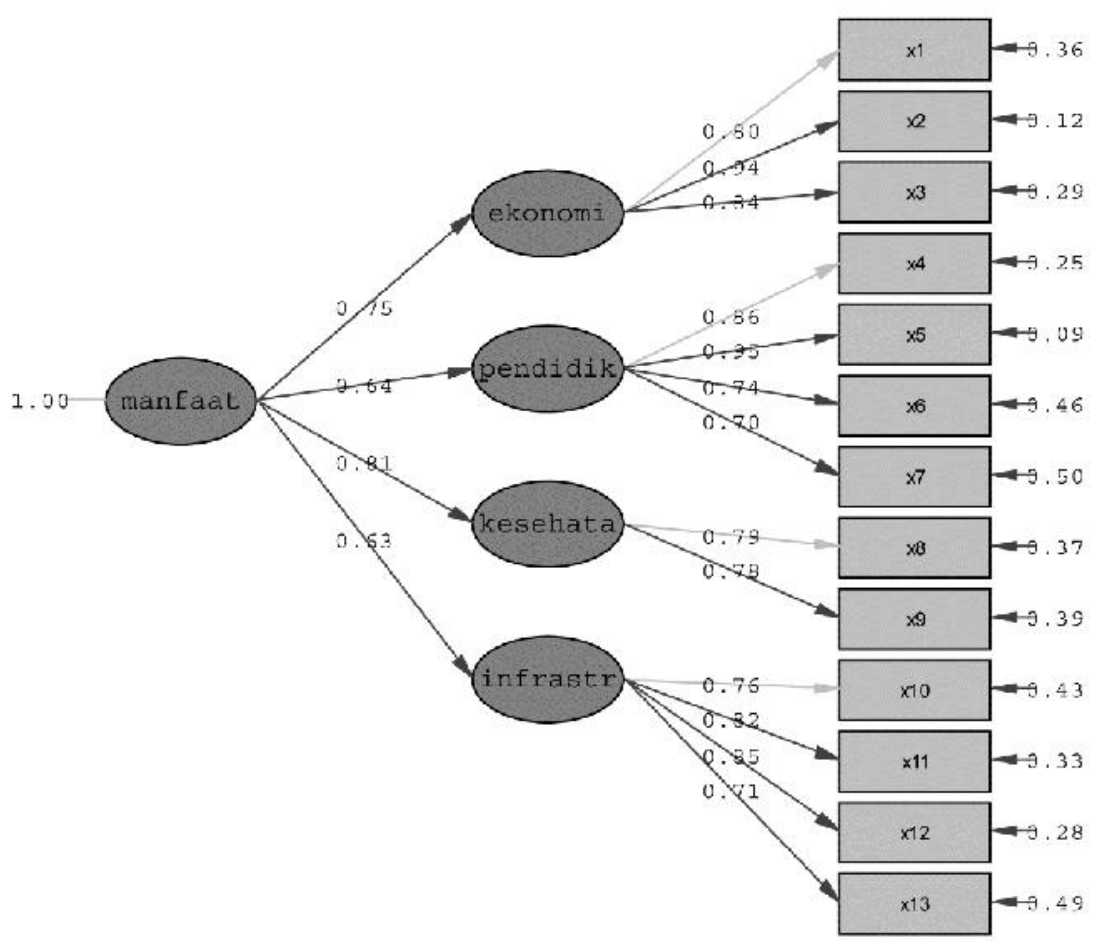

Gambar 1 Model 2nd CFA pada analisis manfaat

Berdasarkan hasil analisis seperti yang terlihat pada gambar di atas, setiap sektor bantuan comdev dapat dirasakan manfaatnya oleh masyarakat. Manfaat yang paling besar dirasakan oleh masyarakat adalah comdev di bidang kesehatan. Bantuan di bidang kesehatan diberikan dalam bentuk bantuan pengobatan gratis, peralatan kesehatan untuk puskesmas setempat serta infrastruktur kesehatan lainnya seperti mobil ambulance. Dengan adanya bantuan tersebut, masyarakat mendapatkan pelayanan kesehatan yang lebih baik serta mendapatkan kemudahan akses dalam berobat.

Manfaat comdev di bidang ekonomi juga dirasakan manfaatnya oleh masyarakat. Bantuan comdev di bidang ekonomi memberikan peluang kepada masyarakat untuk membuka usahanya sendiri, yang berdampak pada peningkatan pendapatan masyarakat setempat. Penyaluran bantuan melalui pemberian serta pinjaman modal usaha dirasakan 
masyarakat cukup membantu masyarakat untuk membuka serta memperluas usaha bahkan membuka lapangan pekerjaan. Selain dalam bentuk bantuan modal, salah satu program comdev adalah memberikan pelatihan dan pendampingan kepada masyarakat untuk membangun usaha madiri. Meskipun demikian, tidak semua usaha mandiri tersebut dapat berlanjut setelah program dari perusahaan selesai. Hal ini dikarenakan tidak adanya pengawasan yang dilakukan pasca pelaksanaan, disisi lain masyarakat penerima bantuan tersebut memiliki kemampuan pengelolaan yang masih minim sehingga banyak ditemukan usaha yang tutup.

Bantuan dibidang pendidikan yang paling dirasakan manfaatnya oleh masyarakat adalah bantuan biaya pendidikan. Dengan adanya program beasiswa masyarakat merasa terbantu dalam hal pembiayaan pendidikan. Bantuan dalam bentuk pembuatan perpustakaan keliling serta bantuan alat peraga pendidikan berdampak pada peningkatan ketrampilan dan pengetahuan, sedangkan bantuan untuk perbaikan dan pembangunan sarana pendidikan memungkinkan masyarakat untuk memperoleh sarana pendidikan yang lebih baik.

Dibidang infrastruktur, comdev diberikan dalam bentuk pembangunan dan perbaikan sarana dan prasarana umum, seperti perbaikan dan pembangunan jalan dan jembatan, pembangunan sarana air bersih, listrik masuk desa, serta pembangunan dan perbaikan fasilitas umum lainnya. Dengan adanya perbaikan dan pembangunan jalan dan jembatan membuat masyarakat mempermudah akses dalam kebupaten maupun keluar kabupaten yang berdampak positif pada kemudahan akses masyarakat ke pusat perekonomian. Meskipun demikian, program-program yang dikucurkan belum mampu untuk mengatasi dampak negatif dari adanya kegiatan pertambangan terutama di bidang lingkungan.

Bantuan dalam bidang kesehatan dan ekonomi memiliki besaran loading faktor yang lebih besar jika dibandingkan dengan sektor lainnya (infrastruktur dan pendidikan). Hal ini dikarenakan kedua sektor ini manfaatnya dapat dirasakan secara langsung oleh masyarakat penerima (dalam jangka pendek). Sedangkan pendidikan merupakan suatu bentuk investasi jangka panjang, dimana manfaatnya tidak dapat dirasakan langsung oleh masyarakat. Sedangkan bantuan infrastruktur merupakan jenis bantuan yang lebih berupa prasarana, dimana diperlukan peran serta dari masyarakat itu sendiri sehingga manfaatnya dapat dirasakan. Seperti bantuan untuk pembuatan dan perbaikan jalan dan jembatan, dimana jika masyarakat masyarakat dapat memanfaatkannya dengan baik, misalnya untuk memperluas akses usaha mereka, maka bantuan tersebut akan memberikan manfaat yang positif bagi perekonomiannya. Sebaliknya jika masyarakat setempat tidak dapat memanfaatkan bantuan tersebut maka comdev yang disalurkan tidak akan memberikan dampak yang positif bagi kesejahteraan masyarakat setempat.

Kegiatan pertambangan tidak pernah lepas dari isu lingkungan. Demikian juga kegiatan pertambangan batubara yang dilakukan di Kabupaten Tanah Bumbu. Isu lingkungan yang paling utama adalah terjadinya pencemaran lingkungan, baik air, udara, tanah, maupun suara. Di beberapa wilayah, pencemaran lingkungan menjadi salah satu pemicu konflik antara perusahaan dengan masyarakat, seperti konfik yang terjadi antara petani di Kecamatan Sungai Loban dengan perusahaan, dimana akibat adanya pencemaran tanah dan air akibat eksplorasi batubara yang berdampak pada berkurangnya kesuburan tanah sehingga tidak dapat ditanami kembali. Selain itu, di Tanah Bumbu banyak ditemukan danau yang muncul ketika musim penghujan yang merupakan bekas area tambang yang tidak direklamasi, kegiatan pertambangan tersebut biasanya yang dilakukan oleh perusahan kecil serta penambang ilegal. Dibidang transportasi, pertambangan juga menimbulkan dampak yang cukup fatal, dimana pembuangan limbah tambang ke sungai berakibat pada pendangkalan sungai, yang mana sungai merupakan salah satu sarana transportasi di Kabupaten Tanah Bumbu. 
Salah satu tujuan dari program comdev adalah untuk meredam isu lingungan yang muncul, salah satunya melalui program bina lingkungan. Meskipun demikian, program tersebut tidak cukup mengatasi permasalahan lingkungan yang muncul. Selain itu, comdev di bidang lingkungan merupakan suatu objek yang sulit untuk diukur tingkat keberhasilannya. Hal ini dikarenakan kerusakan lingkungan yang muncul akibat pertambangan bukanlah hal yang dapat diselesaikan secara instan. Diperlukan waktu yang cukup lama serta penanganan khusus untuk dapat mengembalikan kelestarian lingkungan.

Berdasarkan hasil analisis terlihat bahwa manfaat dari comdev telah dirasakan oleh masyarakat penerimanya. Hal ini menunjukkan bahwa perusahaan tambang batubara, melalui pelaksanaan comdev memberikan kontribusi dalam upaya peningkatan kesejahteraan masyarakat. Pada awalnya comdev mungkin merupakan salah satu cara perusahaan untuk meredam tekanan dari masyarakat setempat, namun dalam perkembangannya program tersebut mampu merubah keadaan masyarakat setempat, bahkan sebagian program memberikan pengaruh yang signifikan daripada programprogram yang diluncurkan oleh pemerintah (Proyogo et al. 2012). Meskipun jika dikaji lebih lanjut, maka akan terlihat bahwa penyaluran dana comdev lebih banyak dialokasikan untuk program-program yang manfaatnya dapat dirasakan secara langsung oleh penerimananya (jangka pendek). Hal ini dikarenakan comdev juga merupakan strategi perusahaan untuk menjaga eksistensi perusahaan di wilayah tersebut dimana masyarakat akan memberikan sambuatan yang positif jika perusahaan tersebut mampu memberikan pengaruh postif yang manfaatnya dapat dirasakan langsung oleh masyarakat. Meskipun demmikian, comdev memiliki keterbatasan dalam penyaluran bantuannya, dimana penyaluran comdev sangat dipengaruhi oleh lokasi. Daerah yang dekat dengan perusahaan maupun tambang akan mendapat bantuan yang lebih besar dan lebih bervariasi daripada daerah yang jauh, sehingga jika dilihat secara spasial, maka manfaat yang diterima oleh masyarakat berbeda-beda disetiap wilayah.

Tambang merupakan sumber daya alam yang tidak dapat diperbarui, sehingga suatu saat akan habis sehingga sehingga manfaatnya pun akan terhenti. Disisi lain, batubara juga merupakan sumber daya bersama (common pool resource), dimana pengelolaannya digunakan untuk meningkatkan kesejahteraan rakyat. Meskipun demikian, pertambangan tidak hanya memiliki dampak postif, dampak negatif yang ditimbulkan akibat adanya kegiatan pertanbangan juga cukup banyak. Sebagaimana diketahui bahwa pertambangan batubara di Tanah Bumbu dikelola oleh pihak swasta, meskipun telah mendapatkan ijin serta ada pengawasan dari pemerintah. Meskipun demikian, masih banyak ditemukan pertambangan batubara yang dilakukan secara ilegal. Pertambangan ilegal serta persaingan antar perusahaan inilah yang menyebabkan munculnya tragedy of the common. Untuk menghindari terjadinya tragedy of the common, penguatan kelembagaan sangat diperlukan. Penguatan kelembagaan yang dimaksud, dimulai dari satuan terkecil yaitu masyarakat lokal sebagai domain pertabambangan batubara, perusahaan tambang sebagai pengelola pertambangan serta pemerintah sebagai pengawas kegiatan pertambangan.

Masyarakat lokal merupakan pihak yang paling merasakan dampak negatif dari adaya kegiatan pertambangan, oleh karenanya masyarakat harus memiliki aturan-aturan tertentu yang menentukan batas-batas dalam kegiatan pertambangan. Selain itu, adanya aturan dalam masyarakat akan mencegah terjadinya penambangan ilegal. Pemerintah merupakan pihak yang memiliki kekuasaan untuk memnetukan batas eksplorasi pertambangan. Selama pemerintah memegang teguh peraturan yang telah ditetapkan dan berani memberikan sanksi terhadap pelanggaran yang dilakukan maka tragedy of the common akan terhindari. Namun pada kenyataannya, terkadang pemerintah menutup mata atas penyimpangan yang dilakukan oleh perusahaan tambang. Demikian juga perusahaan tambang, selama eksplorasi tambang yang dilakukan sesuai dengan aturan- 
aturan yang berlaku serta masih memperhatikan kearifan lokal, maka tidak akan terjadi permasalahan dalam kegiatan ekplorasi pertambangan.

Salah satu wujud perusahaan untuk menghormati kearifan lokal yang dimiliki adalah dengan adanya kegiatan comdev. Dimana comdev merupakan suatu program yang dananya dialokasikan dari keuntungan perusahaan yang berorientasi pada kebutuhan masyarakat. Meskipun demikian, comdev juga bukan merupakan program yang akan ada selamanya. Seperti yang telah dijelaskan, dana comdev berasal dari keuntungan perusahaan, demikian comdev akan ada selama perusahaan tersebut masih beroperasi. Selain itu, comdev juga dimaksudkan untuk meminimumkan dampak negatif yang muncul akibat kegiatan pertambangan. Kebalikan dari comdev, dampak negatif dari kegiatan pertambangan akan tetap ada bahkan setelah tidak ada lagi kegiatan pertambangan. Oleh karena itu, comdev yang dilakukan seharusnya dapat memberikan dampak dalam jangka panjang, dalam artian manfaat comdev masih dapat dirasakan bahkan setelah tidak ada lagi program comdev. Namun, program comdev yang ada saat ini masih belum memberikan manfaat dalam jangka panjang.

Pada umumnya, program comdev diberikan dalam bentuk bantuan yang mudah dirasakan manfaatnya dalam jangka pendek serta hanya bersifat lokal dalam artian hanya dapat dirasakan oleh wilayah penerima bantuan. Program yang ada saat ini belum mampu menciptakan keterkaitan antar wilayah sehingga terjadi ketimpangan ekonomi antar wilayah yang lokasinya dekat dengan pertambangan dengan wilayah yang jauh. Hal ini dikarenakan penyaluran dana comdev masih sangat bergantung pada kedekatan suatu wilayah dengan pertambangan.

\section{Kontribusi Comdev Terhadap Peningkatan Kualitas Sumber Daya Manusia}

Pembangunan wilayah merupakan suatu kegiatan pembangunan yang mencakup aspek pertumbuhan, pemerataan dan berkelanjutan yang berdimansi ruang yang terkait dengan aspek sosial ekonomi wilayah dimana penekannyannya lebih kepada mewujudkan pertumbuhan ekonomi (Anwar et al. 1996). Pembangunan wilayah tidak hanya mencakup aspek fisik saja, tetapi juga aspek sosial dan ekonominya. Salah satu cara untuk menempuh terwujudnya pembangunan wilayah yang berkelanjutan adalah dengan community economic development (CED) dimana pembangunan wilayah mengintegrasi dimensi ekonomi, sosial dan lingkungan dalam jangka panjang (Ross et al. 1987; Roseland 2000). CED dimaksudkan untuk menciptakan pertumbuhan perekonomian wilayah berdasarkan pada kemandirian komunitas. Pertumbuhan ekonomi wilayah salah satunya tergambar dari pertambahan pendapatan masyarakat secara keseluruhan yang terjadi di wilayah tersebut (Priyarsono dan Sahara 2007). Dalam konteks tersebut, peningkatan pendapatan masyarakat dilakukan melalui optimalisasi pemanfaatan sumber daya yang ada sesuai dengan potensi masyarakat. Dengan demikian, pertumbuhan ekonomi tidak dapat dipisahkan dari peningkatan human development yaitu kreativitas dan produktivitas dari masyarakat (Ranis et al. 2000).

Comdev merupakan suatu program yang bertujuan untuk peningkatan kesejahteraan masyarakat disekitar lingkungan tambang, yang dalam penelitian ini didekati dengan nilai indeks pembangunan manusia (IPM). Dalam penelitian ini, kontribusi comdev terhadap peningkatan kualitas sumber daya manusia dianalisis menggunakan analisis regresi dengan metode analisis komponen utama.

Model regresi linear merupakan persamaan regresi yang menggambarkan hubungan antara peubah bebas (satu atau lebih) dengan peubah tak bebas, dimana dugaan hubungan keduanya dapat digambarkan sebagai garis lurus (Juanda 2009). Analisis regresi yang digunakan merupakan model regresi dengan menggunakan komponen utama. Penggunaan komponen utama diperlukan karena adanya 
multikolinieritas antar peubah bebas yang digunakan sehingga jika dilakukan pendugaan dengan teknik Ordinary Least Square (OLS) menyebabkan dugaan yang diperoleh menjadi tidak tepat (Kutner et al. 2004). Analisis komponen utama (AKU) merupakan suatu metode analisis untuk mengidentifikasi komponen yang tidak berkorelasi dari variabel yang berkorelasi. Tujuan utama dari AKU adalah mentransformasi matriks yang berisi variabel-variabel yang saling berkorelasi menjadi bentuk yang lebih sederhana dan tidak berkorelasi namun dapat menggambarkan seluruh informasi dari variabel aslinya (Kim et al. 2012).

IPM merupakan salah satu parameter yang digunakan untuk mengukur kualitas sumber daya manusia. Secara umum, IPM diukur melalui pendekatan tiga dimensi dasar, yaitu pendidikan, kesehatan, serta ekonomi. Dalam perhitungan BPS, parameter yang digunakan untuk mengukur IPM adalah angka harapan hidup waktu lahir yang mewakili dimensi kesehatan, pengeluaran riil perkapita yang mewakili dimensi ekonomi, serta angka melek huruf dan rata-rata lama sekolah yang mewakili dimensi pendidikan. Comdev merupakan salah satu upaya untuk meningkatkan kesejahteraan masyarakat setempat yang salah satunya tergambar dari peningkatan kualiatas sumber daya manusia. Oleh karenanya, seperti halnya dimensi yang menyusun IPM, penyaluran dana comdev juga disalurkan melalui sektor-sektor yang bertujuan untuk peningkatan kualitas sumber daya manusia, yaitu sektor ekonomi, pendidikan, dan kesehatan serta infrastruktur sebagai prasarananya.

Dalam penelitian ini, untuk melihat kontribusi comdev terhadap IPM digunakan model sebagai berikut:

$\begin{array}{ll}\mathrm{Y}_{\mathrm{t}} & =\beta_{0}+\beta_{1} \mathrm{X}_{1 \mathrm{t}}+\beta_{2} \mathrm{X}_{2 \mathrm{t}}+\beta_{3} \mathrm{X}_{3 \mathrm{t}}+\beta_{4} \mathrm{X}_{4 \mathrm{t}}+\beta_{5} \mathrm{X}_{5 \mathrm{t}}+\mathrm{t} \\ \text { Dimana } \mathrm{Y}_{\mathrm{t}} & : \text { nilai IPM pada tahun ke- } \mathrm{t} \\ \mathrm{X}_{1 \mathrm{t}} & : \text { dana comdev pada tahun ke-t } \\ \mathrm{X}_{2 \mathrm{t}} & : \text { realisasi belanja daerah dibidang pendidikan pada tahun ke-t } \\ \mathrm{X}_{3 \mathrm{t}} & : \text { realisasi belanja daerah dibidang kesehatan pada tahun ke- } \mathrm{t} \\ \mathrm{X}_{4 \mathrm{t}} & : \text { realisasi belanja daerah dibidang infrastruktur pada tahun ke- } \mathrm{t} \\ \mathrm{X}_{5 \mathrm{t}} & : \text { nilai PDRB pada tahun ke-t } \\ \beta_{\mathrm{i}} & \text { dimana } \mathrm{i}=0,1,3,4,5,6: \text { nilai koefisien regresi } \\ \varepsilon_{\mathrm{t}} & : \text { error }\end{array}$

Adapun hasil analisis regresi yang diperoleh adalah:

Tabel 2 Hasil analisis regresi

\begin{tabular}{llccc}
\hline Variabel bebas & Elastisitas & Elastisitas & t-hitung & p-value \\
\hline Constant & 58.7601 & & & \\
X1 & $(1.22 \times 10-5)$ & 0.007 & 6.55 & 0.00 \\
X2 & $(8.25 \times 10-6)$ & 0.021 & 23.92 & 0.00 \\
X3 & $(1.23 \times 10-5)$ & 0.001 & 17.28 & 0.00 \\
X4 & $(2.14 \times 10-6)$ & 0.001 & 9.14 & 0.00 \\
X5 & $(3.56 \times 10-7)$ & 0.637 & 23.21 & 0.00 \\
\hline
\end{tabular}

Berdasarkan hasil analisis regresi yang diperoleh, terlihat bahwa semua slope memiliki koefisien positif, yang berarti bahwa setiap kenaikan dari masing-masing variabel bebas memberikan dampak yang positif bagi kualitas sumber daya manusia yang diukur dengan menggunakan IPM. Hasil tersebut sesuai dengan teori yang menyatakan bahwa pengembangan SDM dapat dilakukan dengan perbaikan kualitas sumber daya manusia yang dapat dilakukan melalui sektor pendidikan dan kesehatan (Mankiw 2008). Salah satu langkah yang ditempuh oleh pemerintah adalah dengan meningkatkan belanja pemerintah di bidang pendidikan dan kesehatan. Dana comdev yang juga dialokasikan dalam sektor 
pendidikan dan kesehatan terukti memberikan pengaruh dalam peningkatan kualitas SDM. Selain kedua sektor tersebut, peningkatan kualiatas SDM juga dipengaruhi oleh ada atau tidaknya infrastruktur yang menunjang investasi terhadap SDM. Oleh karena itu, baik pemerintah daerah maupun perusahaan tambang juga memberikan alokasi khusus di bidang infrastruktur.

Seperti halnya pengaruh comdev terhadap perekonomian wilayah, pengaruh comdev dibidang sumber daya manusia juga jauh lebih kecil jika dibandingkan dengan program-program pemerintah yang direpresentasikan dari realisasi belanja pemerintah. Hal ini dikarenakan investasi dibidang sumber daya manusia merupakan investasi jangka panjang, sedangkan comdev di Tanah Bumbu merupakan program yang baru dilaksanakan secara intensif sejak tahun 2011, sehingga wajar jika pengaruhnya lebih kecil jika dibandingkan dengan program pmerintah. Selain itu, mayoritas program comdev ditujukan untuk kegiatan yang bersifat jangka panjang, sehingga pengaruh untuk jangka panjangnya masih kurang dirasakan.

Perekonomian wilayah yang diukur dengan PDRB, merupakan variabel yang sangat berpengaruh dalam peningkatan kualitas sumber daya manusia. Hal ini terlihat dari tingginya nilai elastisitas dari PDRB. Dengan demikian, dapat disimpulkan bahwa suatu wilayah dengan perekonomian wilayah yang baik akan memiliki kualitas sumber daya manusia yang baik juga. Faktor lain yang juga memegang peranan penting dalam peningkatan kualitas sumber daya manusia adalah relisasi belanja di bidang pendidikan, dimana semakin besar belanja pemerintah untuk pendidikan maka akan mempercepat peningkatan kualitas sumber daya manusianya. Dana comdev meskipun memberikan pengaruh dalam pembentukan sumber daya manusia, namun memberikan kontribusi yang sangat kecil dalam peningkatan kualitas sumber daya manusia. Hal ini dikarenakan mayoritas program comdev dialokasikan untuk pembagunan infrastruktur/fisik. Sedangkan bantuan yng bersifat non fisik dirasa masih belum mampu untuk menciptakan manfaat jangka panjang.

\section{KESIMPULAN}

Secara umum, masyarakat telah merasakan manfaat dari program comdev yang disalurkan melalui sektor ekonomi, pendidikan, kesehatan dan infrastruktur walaupun manfaat yang dirasakan lebih mengarah pada manfaat dalam jangka pendek. Meskipun demikian, jika dilihat secara spasial manfaat yang dirasakan oleh masyarakat di masingmasing wilayah berbeda, hal ini dipengaruhi oleh kebutuhan masyarakat, lokasi serta lamanya eksplorasi pertambangan yang dilakukan di wilayah tersebut.

Program comdev yang sudah ada di Kabupaten Tanah Bumbu meskipun memberikan manfaat bagi masyarakat setempat tetapi dirasa masih belum mampu untuk mengatasi permasalahan lingkungan yang muncul akibat kegiatan pertambangan.

Program comdev di Kabupaten Tanah Bumbu memberikan pengaruh yang signifikan dalam kualitas sumber daya manusia di Kabupaten Tanah Bumbu meskipun pengaruh yang diberikan masih jauh lebih rendah jika dibandingkan dengan program yang diberikan oleh pemerintah.

\section{DAFTAR PUSTAKA}

Alfitri. 2010. Program community development perusahaan migas dalam penguatan modal sosial [Disertasi]. Bandung (ID): Universitas Padjajaran.

Anwar A, Hadi S. 1996. Perencanaan Pembangunan Wilayah dan Perdesaan dalam Prisma No. Khusus 25 Tahun 1971 - 1996. Jakarta (ID): LP3ES.

[BPS] Badan Pusat Statistik. 2014. Tanah Bumbu Dalam Angka 2014. Jakarta (ID): BPS. 
Bagozzi RP, Yi Y. 1988. On the evaluation of structural equation models. JAMS. 16(1):74-94.

Budimanta A, Rudito B, Prasetijo A. 2004. Corporate Social Responsibility: Jawaban Bagi Model Pembangunan Indonesia Masa Kini. Jakarta (ID): ICSD.

Donald NB, Suanglin L. 1993. The Differential Effect on Economic Growth of Goverment Expenditures on Education, Welfare, and Defense. JED. 18(1):175-185

Erwiantoro, Saleha Q. 2012. Persepsi dan ekspektasi pembangunan masyarakat terhadap pemerintah daerah dan perusahaan migas. $M S H$. 16(1):57-67.

Juanda B. 2009. Ekonometrika Pemodelan dan Pendugaan. Bogor (ID): IPB Press.

Kim D, Kim SK. 2012. Comparing Patterns of Component Loadings: Principal Component Analysis (PCA) Versus Independent Component Analysis (ICA) in Analyzing Multivariate Non-Normal Data. BR. 44:1239-1243.

Kutner MH, Nachtsheim CJ, Neter J. 2004. Applied Linear Regression Models. 4th ed. Boston (US): McGrawHill Irwin, Inc.

Mankiw NG. 2006. Teori Makroekonomi. 6th. Jakarta (ID): Erlangga.

Prayogo D, Hilarius Y.2012. Efektivitas program CRS/CD dalam pengentasan kemiskinan: studi peran perusahaan geotermal di Jawa Barat. JSM. 17(1):1-22.

Priyarsono DS, Sahara, Firdaus M. 2007. Ekonomi Regional. Jakarta (ID): Universitas Terbuka.

Ranis G, Stewart F, Ramirez A. 2000. Economic growth and human development. WD. 28(2):197-219.

Roseland M. 2000. Sustainability community development: integrating environmental, economic and social objective. PIP. 54(2000).73-132.

Rudito B, Famiola M. 2013. CSR (Corporate Social Responsibility). Bandung (ID): Rekayasa Sains.

Smith CL. 1980. Community wealth concentration: comparisons in general evolution and development. EDCC. 20(4): 801-818.

Sodik J. 2007. Pengeluaran pemerintah dan pertumbuhan ekonomi regional: studi kasus data panel di Indonesia. JEP. 12(1): 27-36.

TATALOKA - VOLUME 18 NOMOR 2 - MEI 2016 - p ISSN 0852-7458 - e ISSN 2356-0266 